\title{
Chitosan-propolis combination inhibits anthracnose in 'Hass' avocados
}

\author{
Ariadne Kaleda Marino', José Sidnaldo Pinsetta Junior', Kelly Marques Magalhães², Ben-Hur Mattiuz ${ }^{1 *}$ \\ ${ }^{1}$ São Paulo State University, School of Agricultural and Veterinarian Sciences, Via de acesso Prof. Paulo Donato Castellane, s/n, \\ Jaboticabal/SP, CEP: 14884-900, Brazil. ${ }^{2}$ University Center Moura Lacerda, Av. Dr. Oscar de Moura Lacerda, 1520, Independência, Ribeirão \\ Preto/SP, 14076-510, Brazil
}

\section{A B S T R A C T}

\begin{abstract}
The effect of chitosan-propolis combination on the control of in vitro and in vivo growth of Colletotrichum gloeosporioides, a causal agent of anthracnose, as well as on the quality of avocado of Hass cultivar has been evaluated. Chitosan and propolis were added to the culture medium separately and in combinations to verify the efficacy of inhibition of $C$. gloeosporioides mycelium in vitro. Avocados were immersed for 1 minute in the treatments that best inhibited the mycelium growth (in vitro) with the aim of testing the fungus control in vivo. The tested treatments were $1.5 \%$ chitosan and combinations of propolis $(1.0 \%, 1.5 \%, 2.0 \%)$ with $1.5 \%$ chitosan and then inoculated with C. gloeosporioides. Control fruits were dipped in distilled water only. In the second experiment, avocados were immersed for 1 minute in the treatments that best inhibited the mycelium growth (in vivo) with the aim of testing the fruits quality. The tested treatments were $1.5 \%$ chitosan isolated and in the combination of $1.5 \%$ chitosan with $1.5 \%$ propolis. The control treatment were immersed only in distilled water. Avocados were stored at $22 \pm 0.3{ }^{\circ} \mathrm{C}$ and $90 \pm 3 \% \mathrm{RH}$ for 7 days. The use of $1.5 \%$ chitosan in combination with $2.0 \%$ propolis controlled the mycelial growth of Colletotrichum gloeosporioides in vitro. In addition, coating with only $1.5 \%$ chitosan provided the best results in avocados, reducing the severity and incidence of anthracnose and maintaining the fruit quality.
\end{abstract}

Keywords: Colletotrichum Gloeosporioides; Natural Products; Persea Americana; Post-Harvest; Quality

\section{INTRODUCTION}

The increasing demand for fruits by consumers relies on the fact that they are sources of vitamins, minerals and can help in prevention of numerous diseases. Avocado (Persea americana Mill.) stands out because it has high nutritional value, which explains its economic importance. It has fibers, proteins, minerals and vitamins, mainly $\mathrm{A}$ and $\mathrm{B}$ (Francisco and Baptistella, 2005; Nieto-Angel et al., 2006; Oliveira, 2000). It also contains a significant amount of unsaturated fatty acids that have beneficial effects in the prevention of cardiovascular diseases (Tango et al., 2004).

The avocados production in Brazil is around 195,000 tons, according to FAO (2016), where Hass and Fuerte cultivars are the most commercialized in the external market. Characteristics of these varieties, such as higher lipid content, smaller diameter, thicker bark and lower water content, in relation to the 'Manteiga' cultivar, makes the pulp more consistent and possible to use in salty dishes. The fruit is the $25^{\text {th }}$ best selling product in CEAGESP, Brazilian main public market, with $46,455.10$ tons of avocado sold in 2016 (CEAGESP, 2018).

Post-harvest fungal diseases represent one of the main causes of tropical fruit losses during the commercialization period (Dantas et al., 2003). Among the diseases, anthracnose caused by the fungus Colletotrichum gloeosporioides, is considered one of the most important diseases of tropical fruits and affects all the avocado producer countries (AvilaQuezada, 2007; Pegg et al., 2002).

Natural products has been shown as an efficient alternative for use in the control of fungal diseases because they have an antimicrobial effect and because they are considered a natural alternative to synthetic fungicides (Combrinck et al., 2011; Kouassia et al., 2012). In this context, we can highlight the propolis that presents chemical compounds with antimicrobial properties (Mattiuz et al., 2015). 
Chitosan, a natural and biodegradable compound, has been used as film or edible coating, also acting to reduce microbial deterioration, proving to be a potential product in the protection of plants against pathogens (BautistaBaños et al., 2006). This polymer have an effect on the control of post-harvest pathogens when applied alone or in combination with other natural products (Ramos-García et al., 2012).

The aim of this study was to evaluate the chitosan associated with propolis in the control of the in vitro and in vivo growth of Colletotrichum gloeosporioides, causal agent of anthracnose, and its effects on the quality of 'Hass' avocados.

\section{MATERIAL AND METHODS}

C. gloeosporioides was isolated from naturally infected 'Hass' avocados. The natural products, with antifungal properties, were propolis $(\mathrm{P})$ from aqueous extract of Propomax ${ }^{\circledR}$, and chitosan $(\mathrm{C})$ with low molecular weight and degree of deacetylation of $75-85 \%$ (Sigma-Aldrich Co). The chitosan was diluted in distilled water with addition of $1 \%$ acetic acid in the volume and the $\mathrm{pH}$ corrected to 5.6 with $0.1 \mathrm{M}$ $\mathrm{NaOH}$ as described by Jiang and Li (2001).

\section{In vitro experiment}

In a total, the effect of 11 treatments was investigated. The treatments included the incorporation of propolis and chitosan to the culture medium separately or in the combinations such as:

[1] Control (PDA), [2] C1.5\%, [3] P1.0\%, [4] P1.5\%, [5] $\mathrm{P} 2.0 \%$, [6] C1.0\% $+\mathrm{P} 1.0 \%$, [7] C1.0\% $+\mathrm{P} 1.5 \%,[8] \mathrm{C} 1.0 \%$ $+\mathrm{P} 2.0 \%,[9] \mathrm{C} 1.5 \%+\mathrm{P} 1.0 \%,[10] \mathrm{C} 1.5 \%+\mathrm{P} 1.5 \%,[11]$ $\mathrm{C} 1.5 \%+\mathrm{P} 2.0 \%$

Six replicates were performed per treatment. The propolis at different concentrations was incorporated into the culture medium (PDA) at $50-55^{\circ} \mathrm{C}$ after autoclaving. The chitosan solutions were obtained by mixing part of the dissolved product with the PDA culture medium until the desired concentration. In all treatments $0.01 \%$ Tween 80 was added.

The warmed culture media were poured under aseptic conditions (laminar flow chamber), into sterile Petri dishes $9 \mathrm{~cm}$ in diameter. After solidification of the medium, $5 \mathrm{~mm}$ diameter mycelium discs were transferred from the edge of the colonies to the center of the plates containing the treatments. The plates, containing the fungus, were maintained at $27 \pm 1^{\circ} \mathrm{C}$ and photoperiod of $12 \mathrm{~h}$.

The mycelial growth of the fungus was measured daily with the aid of a digital caliper (Mitutoyo, model CD-6), until the mycelium of one of the treatments reached the edge of the Petri dish. The percentage inhibition of mycelial growth was calculated by the formula of Yang et al. (2011):

$\mathrm{IM}=\frac{\mathrm{dc}-\mathrm{dt}}{\mathrm{dc}-\mathrm{di}}$

Where: $\mathrm{IM}=$ percentage of mycelial inhibition; $\mathrm{dc}=$ is the mean diameter of the control colony; $\mathrm{dt}=$ is the mean diameter of the treatment colony; $\mathrm{di}=$ is the initial diameter of the fungal colony on the plates.

\section{In vivo experiment - effect on fungus control in avocados}

'Hass' avocados were harvested at Jaguacy company located in the municipality of Bauru (22 $147^{\prime}$ ' $\mathrm{S}$ and $49^{\circ} 8^{\prime} 27^{\prime}$ ' W, $532 \mathrm{~m}$ altitude), at the stage of physiological maturation. The fruits were washed with neutral detergent, rinsed in running water and sanitized in Sumaveg ${ }^{\circledR}$ solution (Sodium Dichloroisocyanurate Dihydrate) at $0.33 \%$, for 5 minutes.

The suspension of conidia of Colletotrichum gloeosporioides was obtained by surface scraping of the colonies in the presence of distilled and sterilized water, and $0.01 \%$ Tween 80 , and after that, the filtration was done on sterilized Whatman filter paper, obtaining a conidial suspension of the pathogen in the concentration of $2 \times 10^{5}$ conidia $\mathrm{mL}^{-1}$.

The fruits were inoculated through wounding with chromatography syringe at two opposite points in the equatorial region., The inoculated volume was $25 \mu \mathrm{L}$ of the conidial suspension of C. gloeosporioides $\left(2 \times 10^{5}\right.$ conidia $\mathrm{mL}^{-1}$ ), and then stored for $10 \mathrm{~h}$ at $22^{\circ} \mathrm{C}$, for fungus colonization. After this period, the fruits were immersed for 1 minute in the combinations of propolis and chitosan that best inhibited fungus mycelial growth in vitro: [1] Control - water dipped, [2] C1.5\%, [3] C1.5\% + P1.0\%, [4] C1.5\% $+\mathrm{P} 1.5 \%$, [5] C1.5\% + P2.0\%.

After drying and coating, the fruits were stored at $22 \pm 0.3{ }^{\circ} \mathrm{C}$ and $94 \pm 5.5 \% \mathrm{RH}$.

The experiment was conducted in a completely randomized design, consisting of five treatments ( 4 concentrations + control). Four replicates were used with 5 fruits each.

After 7 days, the disease setverity analyzes were performed by measuring the size of the lesion in two perpendicular directions on the fruit; and the incidence of the disease was determined according to Xing et al. (2010) using the following equation:

Incidence of disease $(\%)=\frac{\text { Number of infected wounds }}{\text { Total number of inoculated fruits }} \times 100$

Emir. J. Food Agric • Vol $30 \bullet$ Issue 8 • 2018 


\section{In vivo experiment - effect of treatments on fruit quality}

Avocados were immersed for 1 minute in the treatments $(\mathrm{C} 1.5 \%$ and $\mathrm{C} 1.5 \%+\mathrm{P} 1.5 \%)$. These treatments are chosen based on results of second experiment and chosen treatments showed best performances in fungus control in comparison to other treatments. In the control treatment, fruits were immersed only in water.

The experiment was conducted in a completely randomized design, consisting of 3 treatments ( 2 concentrations + control). Four replicates were used with 5 fruits each.

The fruits respiration rate and the ethylene production were evaluated according to the methodology of Marques (2015).

The content of acetaldehyde and ethanol were determined according to methodology adapted from Davis (1969). Samples of $1 \mathrm{~g}$ of crushed pulp were transferred to $50 \mathrm{~mL}$ flasks, sealed and stored frozen until analysis. Prepared samples were incubated in a water bath on a $50{ }^{\circ} \mathrm{C}$ for 30 minutes. After 30 minutes, $1.0 \mathrm{~mL}$ of headspace air of the flask was collected and injected into Trace GC Ultra, Thermo Scientific, equipped with (FID) and Porapack $\mathrm{N}$ column separation. The acetaldehyde and ethanol contents were calculated by correlating the respective chromatographic areas with those obtained in the standard curves. Results were expressed as $\mu \mathrm{g}$ acetaldehyde or ethanol per gram of plant material.

\section{Data analysis}

Data were subjected to analysis of variance (ANOVA) to examine the effects of treatments and their interactions. The means values of treatments and interactions with significant effect were compared by the Tukey test $(\mathrm{P} \leq 0.05)$. Statistical analyzes were performed using Sisvar software, version 5.6 and graphs were made using GraphPad Prism software, version 6.0.

\section{RESULTS AND DISCUSSION}

\section{Effect of propolis and chitosan on the mycelial growth of Colletotrichum gloeosporioides}

The isolated effect of the natural products in the inhibition of mycelial growth in vitro showed that for propolis, the concentration of $2.0 \%$ obtained the highest percentage of inhibition (83\%) (Fig. 1). Mattiuz et al. (2015) demonstrated that the concentration of $2.5 \%$ of ethanolic propolis extract (EPE) controlled in 100\% the in vitro mycelial growth of C. gloeosporioides. Similarly, EPE of Chinese origin prevented the in vitro mycelial growth of Penicillium italicum (Yang et al., 2011). Propolis has demonstrated broad spectrum antimicrobial activity

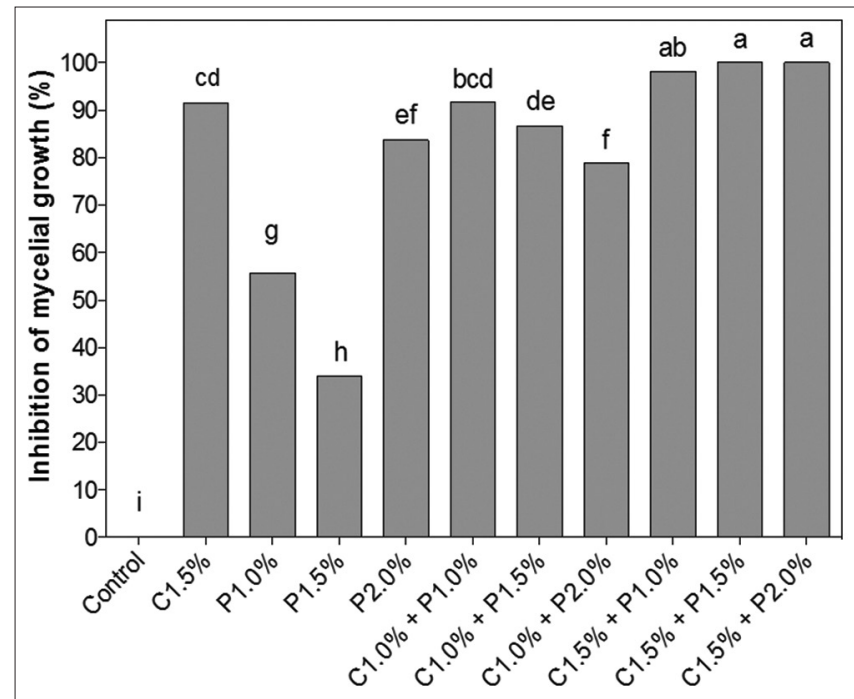

Fig 1. Effect of propolis and chitosan on the mycelial growth of Colletotrichum gloeosporioides after 7 days at $27^{\circ} \mathrm{C}$. Means with equal lowercase letters do not differ from each other, by the Tukey test $(P<0.05)(n=6) . C=$ chitosan; $P=$ propolis.

against bacterial species, yeast, and various fungal species including phytopathogenic fungi such as Botrytis, Aspergillus, Alternaria Nees (Campana et al., 2009; Silici et al., 2005; Umthong et al., 2009). Propolis has chemical compounds such as flavonoids, phenolic acids and esters, quinones, coumarins, sesquiterpenes, and steroids, providing antibiotic properties on it (Markham et al., 1996). According to Castro et al. (2009), flavonoids and phenols are the main natural antibiotic compounds of this product, for example Artepillin-C, present in EPE used by Mattiuz et al. (2005), which has proven antimicrobial activity (Kimoto et al., 2001). These antimicrobial properties described for propolis may explain the favorable results observed in the present study, as well for its action associated with chitosan in the control of the pathogen.

Although propolis at $2.0 \%$ presented high mycelial control $(83 \%)$, treatment with $1.5 \%$ chitosan was superior (91\%) and differed significantly from propolis (Fig. 1). In vitro studies using chitosan at concentrations of $2.5 \%$ and $3.0 \%$ also demonstrated that this product had a fungicidal effect against C. gloeosporioides, controlling mycelial growth, also causing changes in the morphology of the conidia of the pathogen (Bautista-Baños et al., 2003; Bautista-Baños et al., 2006). In addition to this pathogen, scientific studies prove the antimicrobial properties of chitosan in the control of fungi in vitro and in vivo, especially Rizopus Stolonifer, Penicillium digitatum and Fusarium oxysporum (Palou et al., 2016; Romanazzi et al., 2017).

The combination of chitosan at $1 \%$ with increasing concentrations of propolis reduces the inhibition of 
mycelial growth of the fungus. When the concentration of $1.5 \%$ of chitosan is used, there is an inverse effect, that is, the percentage of inhibition increases with the concentration of the associated propolis (Fig. 1).

Chitosan at $1.5 \%$ and propolis at $2.0 \%$ inhibit in vitro growth of the pathogen, with about $91 \%$ and $84 \%$, respectively. However, when we combine chitosan $1.5 \%$ and propolis, we achieved significantly higher results, reaching the control $(100 \%)$ of mycelial growth, in the highest concentrations $(\mathrm{C} 1.5 \%+\mathrm{P} 1.5 \%$ and $\mathrm{C} 1.5 \%+\mathrm{P} 2.0 \%$ ) (Figure 1).

\section{Effect of propolis and chitosan on 'Hass' avocados inoculated with Colletotrichum gloeosporioides}

The severity of the anthracnose was higher in the fruits of the control $(31 \mathrm{~mm})$, which differed significantly from the other treatments (Figure 2A). The best results were verified with the application of chitosan and its combination with the concentrations of 1.5 and $2.0 \%$ of propolis. Comparing with control fruits, the application of chitosan allowed a reduction of $67 \%$ in disease severity in avocados.

Although the incidence of $C$. gloeosporioides in avocados was high, chitosan application at $1.5 \%$ was the treatment that most reduced the incidence of the disease when compared to the fruits of the control (Figure 2B). Many studies have

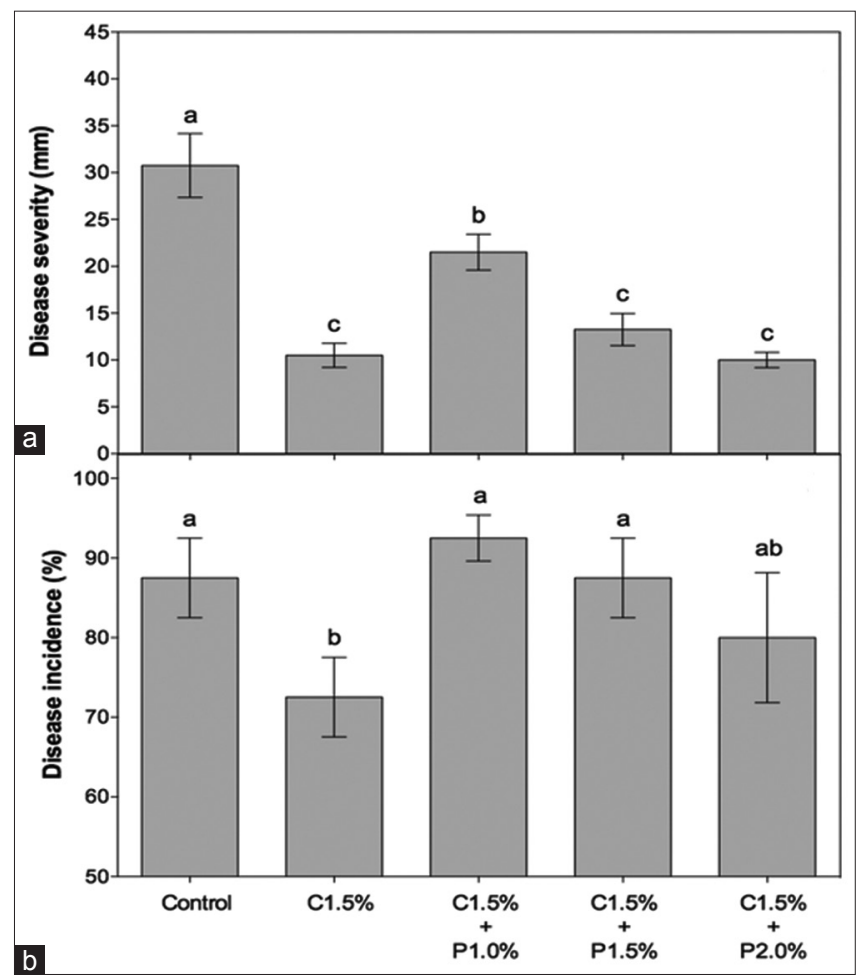

Fig 2. Effect of chitosan and propolis on severity $(A)$ and incidence (B) of anthracnose on 'Hass' avocados inoculated with Colletotrichum gloeosporioides and stored at $22 \pm 0.3^{\circ} \mathrm{C}$ and $94 \pm 5.5 \% \mathrm{RH}$ for 7 days. Averages \pm standard error with equal lowercase letters do not differ by Tukey test $(P<0.05)(n=4)$. $C=$ chitosan; $P=$ propolis. demonstrated that chitosan, isolated or associated with other compounds, is effective in the control of post-harvest pathogens, such as anthracnose caused by C. gloeosporioides in oranges (Deng et al., 2015) and in mangos (Mattiuz et al. 2015), Penicillium digitatum or Penicillium italicum in grapefruit (Zeng et al. 2010), Botrytis cinerea in table grapes (Romanazzi et al., 2012).

There is a considerable interest in the use of chitosan in agriculture because its triple action makes it an ideal coat for post-harvest use of fruits and vegetables: antimicrobial activity in plant pathogens, filmogenic activity that acts as a barrier and ability to develop elicitors that are plant defense mechanisms (Romanazzi et al., 2017).

As for the combination of chitosan with propolis, there is a reduction in both the severity and the incidence of the disease in proportion to the propolis concentration (Fig. 2), similar effect as in vitro growth results (Fig. 1). However, the best result of the combination $(\mathrm{C} 1.5 \%+\mathrm{P} 2.0 \%)$ did not differ significantly from chitosan at $1.5 \%$, demonstrating that, in the case of mycelial growth in fruits, the application of $1.5 \%$ chitosan would be enough to controle the disease.

Effect of the combination of propolis and chitosan on the quality of avocados 'Hass'

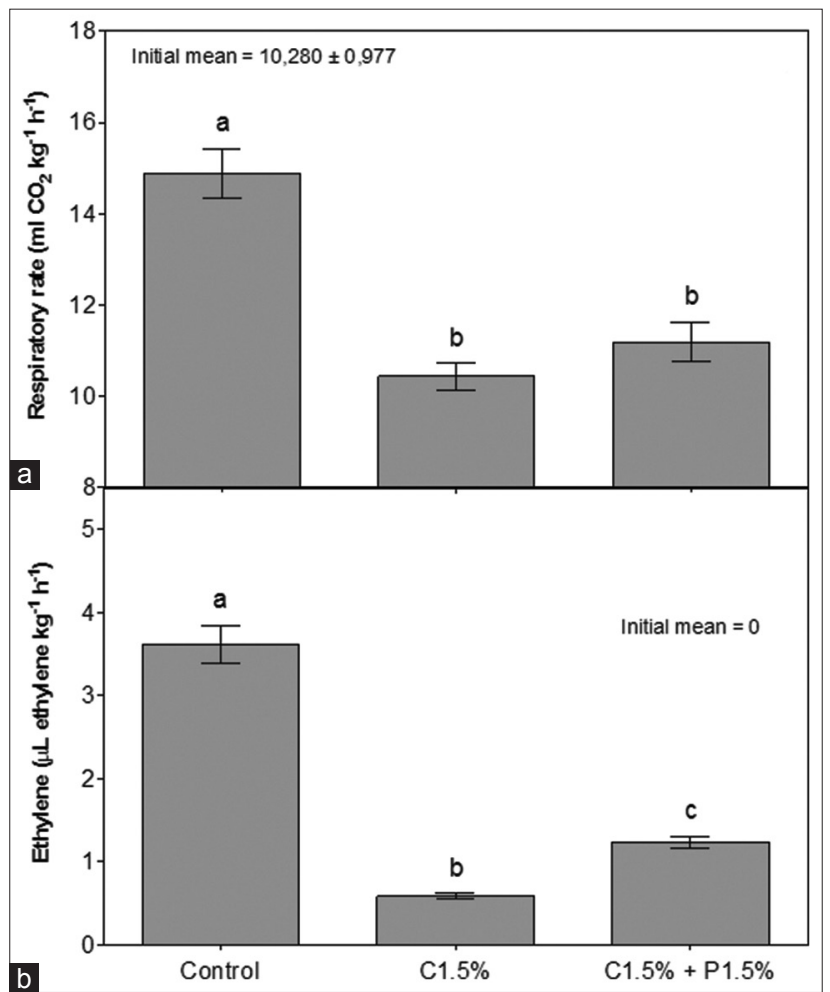

Fig 3. Effect of propolis and chitosan on respiratory rate $(A)$ and ethylene (B) production of 'Hass' avocados stored at $22 \pm 0.3^{\circ} \mathrm{C}$ and $84 \pm 4.2 \% \mathrm{RH}$ for 7 days. Averages \pm standard error with equal lowercase letters do not differ by Tukey test $(P<0.05)(n=4)$. $\mathrm{C}=$ chitosan; $\mathrm{P}=$ propolis. 
The respiratory rate of control fruit increased at the end of the storage time $\left(15 \mathrm{~mL} \mathrm{CO}_{2} \mathrm{~kg}^{-1} \mathrm{~h}^{-1}\right)$, differing significantly from treatments $\mathrm{C} 1.5 \%$ and $\mathrm{C} 1.5 \%+\mathrm{P} 1.5 \%$ (Fig. $3 \mathrm{~A}$ ). Although not significantly different from the $\mathrm{C} 1.5 \%+$ P1.5\% treatment, the treatment with $1.5 \%$ chitosan had the lowest respiratory rate $\left(10.4 \mathrm{~mL} \mathrm{CO}_{2} \mathrm{~kg}^{-1} \mathrm{~h}^{-1}\right)$, with similar means to that of beginning of the evaluation. Similar behavior was observed for the ethylene production of avocados after 7 days of inoculation (Fig. 3B), where the $1.5 \%$ chitosan treatment had the lowest averages $(0.5 \mu \mathrm{L}$ ethylene $\left.\mathrm{kg}^{-1} \mathrm{~h}^{-1}\right)$, significantly different from controls (3.6 $\mu \mathrm{L}$ ethylene $\mathrm{kg}^{-1} \mathrm{~h}^{-1}$ ) and treatment with propolis $\left(1.2 \mu \mathrm{L}\right.$ ethylene $\left.\mathrm{kg}^{-1} \mathrm{~h}^{-1}\right)$.

At ambient temperature, the avocados present a maturation characterized by a rapid increase in the respiratory rate with consequent increase in the ethylene production, characterizing a very fast climacteric peak (Chitarra and Chitarra, 2005; Kosiyachinda and Young, 1975). The results observed in this work show the effect of the coating formed by the natural products used, in the modification of the atmosphere around the fruits, that reduced the respiration rate and the ethylene production, thus increasing the shelf life of the avocados and the maintenance of fruit quality.

The lowest loss of fresh weight occurred in fruits treated with chitosan $1.5 \%(1.8 \%)$, followed by the combination

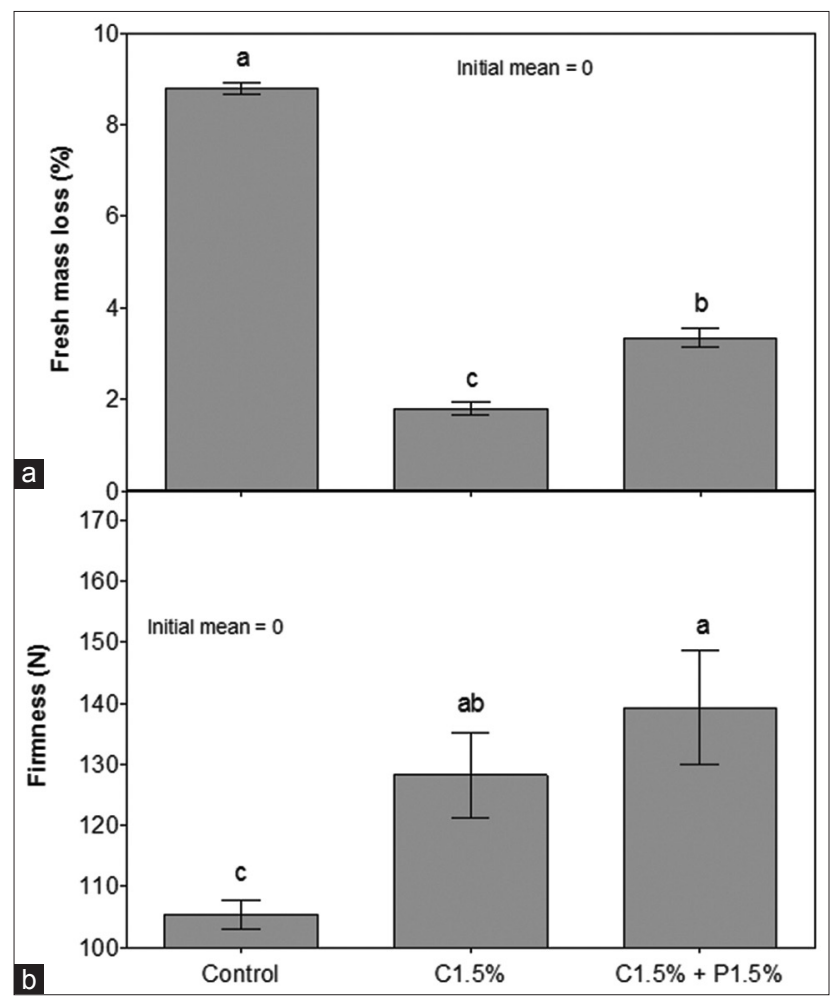

Fig 4. Effect of propolis and chitosan on fresh mass loss (A) and firmness (B) of 'Hass' avocados stored at $22 \pm 0.3^{\circ} \mathrm{C}$ and $84 \pm 4.2 \%$ $\mathrm{RH}$ for 7 days. Averages \pm standard error with equal lowercase letters do not differ by Tukey test $(P<0.05)(n=4)$. $C=$ chitosan; $P=$ propolis. of chitosan with propolis, which differed significantly from the control (8.8\%) (Fig. 4A). The fruits of the control lost 3.9 times more fresh mass than the avocados coating with chitosan. Research has shown that the film formed by chitosan forms a barrier against the diffusion of water vapor, thus reducing the loss of water by the vegetable and consequently its weight loss (Ali et al., 2011; BautistaBaños et al. 2006).

The firmness of the fruit pulp was reduced at the end of the 7 days of storage, and the fruits treated with chitosan at $1.5 \%$ and with propolis associated with chitosan at concentrations of $1.5 \%$ presented higher firmness values when compared to fruits (Fig. 4B). Firmness is a very important qualitative attribute for the consumer, associated with the useful life of the fruits. The maintenance of the firmness of the treated fruits is related to the smaller loss of fresh mass that occurred in these treatments because the fruits with greater cellular turgescence present, consequently, greater resistance to the pressure. Tissue softening (loss of firmness) in fruits is also due to the action of enzymes responsible for the degradation and solubilization of pectins, and by modifications of the cell wall composition (Toivonen and Brummell, 2008). As observed in this work, the formation of a semipermeable barrier in the chitosan avocados allowed the maintenance of firmness both by reducing the loss of fresh mass and by the delay of fruit ripening processes, as observed by several authors (Ali et al., 2011, Silva et al., 2018).

Regarding the content of acetaldehyde produced by avocados, after 7 days of storage, treatments with coating $(\mathrm{C} 1.5 \%$ and $\mathrm{C} 1.5 \%+\mathrm{P} 1.5 \%)$ presented the highest averages when compared to the control treatment (Figure 5A and 5B). These results were expected since, in fruits coated with chitosan, active modified atmosphere conditions occur (Palou et al., 2016). This condition can become beneficial when the $\mathrm{O}_{2}$ content decreases and $\mathrm{CO}_{2}$ levels increase, to the point of creating an ideal modified atmosphere around the fruit, causing a decrease in the metabolic process and, consequently, the extension of the useful life of the fruit or vegetable. However, depending on the type of coating, concentration, application and additives incorporated, the concentration limits of these two gases can be overcome and trigger the anaerobic (fermentative) breathing process, culminating in the development of acetaldehyde and ethanol, which are toxic to cells.

Acetaldehyde is naturally formed during fruit maturation (Pesis, 2005), however, according to Hribar et al. (2000), when the concentration of this compound in the fruits is high, may be toxic to the plant cells and, as a defense mechanism of the fruit, acetaldehyde is quickly converted to ethanol, considered a less toxic substance. 


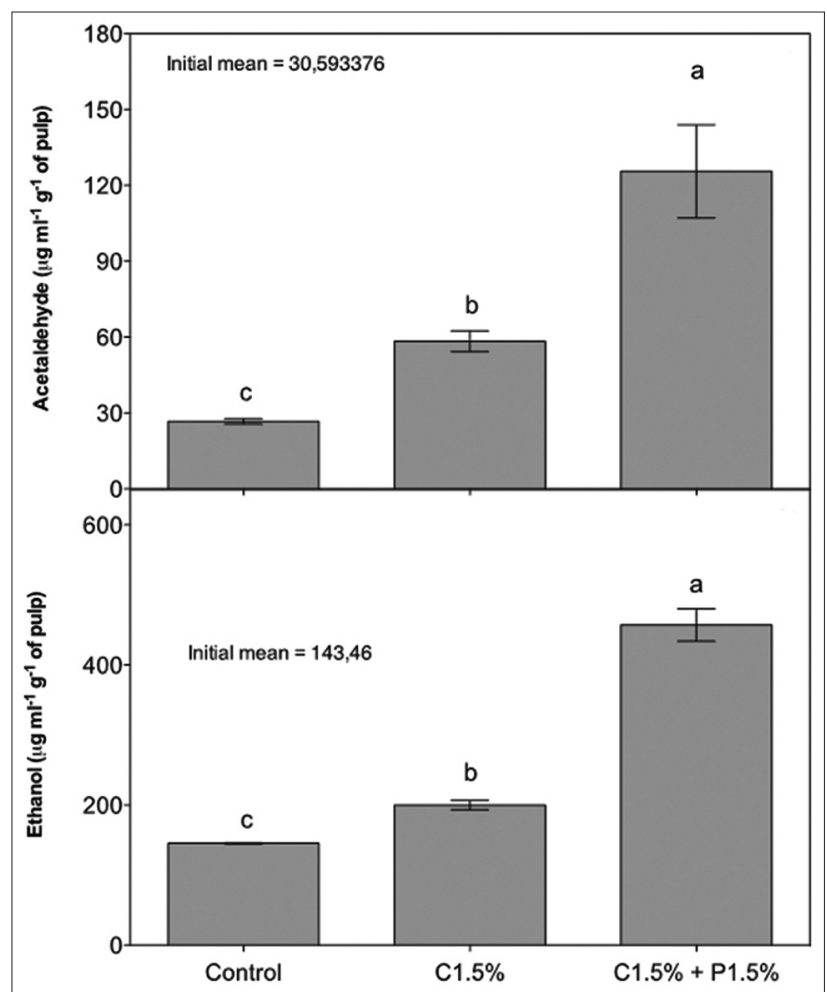

Fig 5. Effect of propolis and chitosan on acetaldehyde (A) and ethanol (B) content of 'Hass' avocados stored at $22 \pm 0.3^{\circ} \mathrm{C}$ and $84 \pm 4.2 \% \mathrm{RH}$ for 7 days. Averages \pm standard error with equal lowercase letters do not differ by Tukey test $(P<0.05)(n=4) . C=$ chitosan; $P=$ propolis.

Table 1: ANOVA analyses of results of Inhibiton of mycelial growth (IMG) in vitro, Disease severity (DS), Disease incidence (DI), Respiratory rate (RR), Fresh mass loss (FML), Firmness (Firm), ACE=Acetaldehyde (ACE), Ethanol (ETA) in "Hass" avocados

\begin{tabular}{lll}
$\begin{array}{l}\text { Sources of } \\
\text { variation }\end{array}$ & \multicolumn{2}{c}{ Probability $>F^{1}$} \\
\cline { 2 - 3 } & IMG DS DI RR Ethylene FML Firm ACE ETA
\end{tabular}

$\begin{array}{lccccccccc}\text { Treatment }(\mathrm{A}) & * * & * * & * * & * * & * * & * * & * * & * * & * * \\ \text { Time (B) } & - & * * & * * & * * & - & - & * * & - & - \\ \text { Interaction } & - & * * & * * & * * & - & - & * * & - & - \\ (\mathrm{A} \times \mathrm{B}) & & & & & & & & & \end{array}$

$\mathrm{IMG}=$ Inhibiton of mycelial growth; $\mathrm{DS}=$ Disease severity; $\mathrm{DI}=$ Disease incidence; $\mathrm{RR}=$ Respiratory rate; $\mathrm{FML}=$ Fresh mass loss; Firm=Firmness; $\mathrm{ACE}=$ Acetaldehyde; $\mathrm{ETA}=$ Ethanol. ${ }^{1 * *} \mathrm{P}<0.01$

Although no changes were observed in the aroma and fruit flavor that indicated the evolution of the fermentation process, which could compromise its organoleptic characteristics, it is expected that a good coating will prevent fruits to produce high levels of acetaldehyde and ethanol. In this study, the coating using $1.5 \%$ chitosan resulted in levels of these compounds closer to the control fruit.

These results showed the positive effect of chitosan and its combination with propolis on fungus control. This polymer may act as a barrier to the flow of nutrients present in fruits and reduce the availability of nutrients for the growth of the pathogen, since chitosan-exposed fungal cells often exhibit signs of nutrient deficiency (Ait Barka et al., 2004, El Ghaouth et al., 2000).

The ANOVA analyses of the experimental results can be find on the Table 1.

\section{CONCLUSIONS}

The chitosan, at a concentration of $1.5 \%$, associated with propolis at $2.0 \%$, promoted the control of the mycelial growth of Colletotrichum gloeosporioides in vitro; while the coating with only $1.5 \%$ chitosan, provided the best results in avocados, reducing the severity and incidence of anthracnose, maintaining fruit quality.

\section{Authors contributions}

A.K.M.: experiments, data analyses, writing of manuscript. J.S.P.J.: writing of manuscript. K.M.M.: experiments, data analysis, writing of manuscript. B.H.M.: Proposal of the research topic, design of experiments, critical revision of manuscript.

\section{REFERENCES}

Ait, Barka, E., P. Eullaffroy, V. Clément and G. Vernet 2004. Chitosan improves development, and protects Vitis vinifera L. against Botrytis cinerea. Plant Cell Rep. 22: 608-614.

Ali, A., M. T. M. Muhammad, K. Sijam and Y. Siddiqui. 2011. Effect of chitosan coatings on the physicochemical characteristics of Eksotika II papaya (Carica papaya L.) fruit during cold storage. Food Chem. 124: 620-626.

Avila-Quezada, G., S. H. V. Rojas and O. D. Teliz. 2007. First report of the anamorph of Glomerella acutata causing anthracnose on avocado fruits in Mexico. Plant Disease. 91: 1200.

Bautista-Baños, S., A. N. Hernandez-Lauzardo, M. G. Velazquez-Del Valle, M. Hernández-Lopez, E. A. Barka, E. Bosquez-Molina and C. L. Wilson. 2006. Chitosan as a potencial natural compound to control pre and postharvest diseases of horticultural commodities. Crop Protection. 25: 108-118.

Bautista-Baños, S., M. Hernández-Lópes, E. Bosquez-Molina and C. L. Wilson. 2003. Effects of chitosan and extracts on growth of colletotrichum gloeosporioides, anthracnose levels and quality of papaya fruit. Crop Protection. 22: 1087-1092.

Campana, R., V. Patrone, I. T. Franzini, G. Diamantini, E. Vittoria and W. Baffone. 2009. Antimicrobial activity of two propolis samples against human Campylobacter jejuni. J. Med. Food. 12: 1050-1056.

Castro, M. L., W. R. Vilela, R. C. Zauli, M. Ikegaki, V. L. Rehder and M. A. Foglio. 2009. Bioassay guided purification of the ntimicrobial fraction of a Brazilian propolis from Bahia state. BMC Complement Altern. Med. 9: 1-6.

CEAGESP. 2018. Companhia de Entrepostos e Armazéns Gerais de São Paulo. Available from: http://www.ceagesp.gov.br/produtos/ abacate-bredamargarida-2/. [Last retrieved on 2018 Feb 17].

Chitarra, M. I. F. and A. B. Chitarra. 2005. Pós-colheita de Frutas e Hortaliças: Fisiologia e Manuseio. UFLA, Lavras. 
Combrinck, S., T. Regnier and G. P. P. Kamatou. 2011. In vitro activity of eighteen essential oils and some major components against common postharvest fungal pathogens of fruit. Indust. Crops Prod. 33: 344-349.

Dantas, S. A. F., S. M. A. Oliveira, S. J. Michereff, L. C. Nascimento, L. M. S. Gurgel and W. R. L. S. Pessoa. 2003. Doenças fúngicas pós-colheita em mamões e laranjas comercializados na central de abastecimento do recife. Fitopatol. Brasil., 28: 528-533.

Davis, P. L. 1969. Relation of ethanol content of citrus fruits to maturity and to storage conditions. Flo. State Hortic. Soc. 83: 294-298.

Deng, L., Y. Zhou and K. Zeng. 2015. Pre-harvest spray of oligochitosan induced the resistance of harvested navel oranges to anthracnose during ambient temperature storage. Crop Prot. 70: $70-76$.

El Ghaouth, A., J. L. Smilanick and C. L. Wilson. 2000. Enhancement of the performance of Candida saitoana by the addition of glycolchitosan for the control of postharvest decay of apple and citrus fruit. Postharvest Postharvest Biology and Technology, 19: 103-110.

FAO. 2016. Food and Agriculture Organization of United Nations. from: Availabl;e from: http://www.fao.org/faostat/en/\#data/QC. [Last retrieved on $2018 \mathrm{Feb}$ 17].

Francisco, V. L. F. S. and C. S. L. Baptistella. 2005. Cultura do abacate no estado de São Paulo. Inform. Econ. 35: 27-41.

Hribar, J., M. Zavrtanik, M. Simcic and R. Vidrih. 2000. Changes during storing and astringency removal of persimmon fruit (Diospyros kaki L.). Acta Aliment. 29: 123-136.

Jiang, Y. M. and Y. B. Li. 2001. Effects of chitosan coating on postharvest life and quality of Longan fruit. Food Chem. 73: 139-143.

Kimoto, T., M. Aga, K. Hino, S. Koya-Miyata, Y. Yamamoto, M. J. Micallef, T. Hanaya, S. Arai, M. Ikeda and M. Kurimoto. 2001. Apoptosis of human leukemia cells induced by Artepillin $C$, an active ingredient of Brazilian propolis. Anticancer Res. 21: 221-228.

Kosiyachinda, S. and R. E. Young. 1975. Ethylene production in relation to the initiation of respiratory climateric fruit. Plant Cell Physiol. 16: 595-602.

Kouassia, K. H. S., M. Bajji and H. Jijakli. 2012. The control of postharvest blue and green molds of citrus in relation with essential oil-wax formulations, adherence and viscosity. Postharvest Biol. Technol. 73: 122-128.

Markham, K. R., K. A. Mitchell, A. L. Wilkins, J. A. Daldy and Y. Lu. 1996. HPLC and GC-MS identification of the major organic constituents in New Zealand propolis. Phytochemistry. 42: 205-211.

Marques, K. M. 2015. Quitosana e Óleos Essenciais no Controle de Antracnose e na Qualidade Pós-colheita de Abacates. (Doctoral Thesis), Universidade Estadual Paulista, Jaboticabal.

Mattiuz, B. H., M. N. Ducamp-Collin, C. F. N. Mattiuz, C. Vigneault, K. M. Marques, W. Sagoua and D. Montet. 2015. Effect of propolis on postharvest control of anthracnose and quality parameters of Kent mango. Sci. Hortic. 184: 160-168.

Nieto-Angel, D., M. Acosta-Ramos, D. T. Ortiz, A. R. São José. 2006. Enfermedades Del Aguacate. In: S. M. A. Oliveira, D. Terao, S. A. F. Dantas and S. C. C. H. Tavares (Eds.), Patologia pósColheita: Frutas, Olerícolas e Ornamentais Tropicais. Embrapa Informação Tecnológica, Brasilia, pp. 473-491.

Oliveira, M. A., C. H. Santos, C. M. Henrique and J. D. Rodrigues.
2000. Ceras para conservação pós-colheita de frutos de abacateiro cultivar Fuerte, armazenados em temperatura ambiente. Sci. Agric. 57: 777-780.

Palou, L., A. Ali, E. Fallik and G. Romanazzi. 2016. Gras, plant- and animal-derived compounds as alternatives to conventional fungicides for the control of postharvest diseases of fresh horticultural produce. Postharvest Biol. Technol. 122: 41-52.

Pegg, K. G., L. M. Coates, L. Korsten and R. M. Harding. 2002. Foliar, fruit and soil diseases. In: A. W. Whiley, B. Schaffer, B. N. Wolstenholme (Eds.), The avocado: Botany, Production and Uses. CAB Intl. Press, Wallingford.

Pesis, E. 2005. The role of the anaerobic metabolites, acetaldehyde and ethanol, in fruit ripening, enhancement of fruit quality and fruit deterioration. Postharvest Biol. Technol. 37: 1-19.

Ramos-García, M., E. Bosquez-Molina, J. HernándezRomano, G. Zavala-Padilha, E. Terrés-Rojas, I. Alia-Tejacal, L. Barrera-Necha, M. Hernández-López and S. Bautista-Baños. 2012. Use of chitosan-based edible coatings in combination with other natural compounds, to control Rhizopus stolonifer and Escherichia coli DH5a in fresh tomatoes. Crop Prot. 38: 1-6.

Romanazzi, G., A. Lichter, F. M. Gabler and J. L. Smilanick. 2012. Recent advances on the use of natural and safe alternatives to conventional methods to control postharvest gray mold of table grapes. Postharvest Biol. Technol. 64: 141-147.

Romanazzi, G., E. Feliziani, S. Baustista-Baños and D. Sivakumar. 2017. Shelf life extension of fresh fruit and vegetables by chitosan treatment. Crit. Rev. Food Sci. Nutr. 57: 579-601.

Silici, S., N. A. Koc, D. Ayangil and S. Canaya. 2005. Antifungal activities of propolis collected by different races of honeybees against yeasts isolated from patients with superficial mycoses. J. Pharm. Sci. 99: 39-44.

Silva, W. B., G. M. C. Silva, D. B. Santana, A. R. Salvador, D. B. Medeiros, I. Belghith, N. M. Silva, N. H. M. Cordeiro and G. P. Misobutsi. 2018. Chitosan delas ripening and ROS production in guava (Psidium guajava L.) fruit. Food Chem. 242: 232-238.

Tango, J. S., C. R. L. Carvalho and N. B. Soares. 2004. Caracterização física e química de frutos de abacate visando a seu potencial para extração de óleo. Rev. Brasil. Fruticul. 6: 17-23.

Toivonen, P. M. A. and D. A. Brummell. 2008. Biochemical bases of appearance and texture changes in fresh-cut fruit and vegetables. Postharvest Biol. Technol. 48: 1-14.

Umthong, S., S. Puthong and C. Chanchao. 2009. Trigona laeviceps propolis from Thailand: Antimicrobial, ant proliferative and cytotoxic activities. Am. J. Chin. Med. 37: 855-865.

Xing, Y., X. Li, Q. Xu, J. Yun and Y. Lu. 2010. Antifungal activities of cinnamon oil against Rhizopus nigricans, Aspergillus flavus and Penicillium expansum in vitro and in vivo fruit test. Int. J. Food Sci. Technol. 45: 1837-1842.

Yang, S. Z., L. T. Peng, X. J. Su, F. Chen, Y. J. Cheng, G. Fan and S. Y. Pan. 2011. Bioassay-guided isolation and identification of antifungal components from propolis against Penicillium italicum. Food Chem. 127: 210-215.

Zeng, K., Y. Deng, J. Ming and L. Deng. 2010. Induction of disease resistance and ROS metabolism in navel oranges by chitosan. Sci. Horticul. 126: 223-228. 